\title{
Daya Saing Mahasiswa dan Mahasiswi di Kawasan Perbatasan Mengikuti Perkuliahan Online Masa Pandemi Covid-19 (Analisis Naratif-Kualitatif)
}

\author{
Desy Irsalina Savitri, Nindya Adiasti, Mety Toding Bua, \\ Sucahyo Mas'an Al-Wahid, Ady Saputra
}

\author{
Universitas Borneo Tarakan \\ desy.irsalinasavitri@gmail.com
}

\section{Article History}

received 9/10/2021

\begin{abstract}
2018 is the year where learning 4.0 is intensified and society 5.0 is relying on social networks through bold paths. Since the pandemic since the beginning of 2020 and since the regulation from the Ministry of Education and Culture regarding face-to-face lectures into online lectures, inevitably almost all people have finally learned about it. Many have difficulty dealing with this actual condition. This article will discuss the competitiveness/competitiveness of PGSD students taking online lectures based on 4.0 learning at the University of Borneo Tarakan during the covid 19 pandemic which was initially face-to-face to online lectures from home. This article is viewed from a qualitative point of view, using a narrative analysis approach. The data analysis presentation will be explained in narrative form. The result is that there are significant differences between students and students taking online lectures, from class 2019 classes A and C. They face many obstacles but the competitive proportion of PGSD students is greater than students in facing obstacles in the online lecture process. When viewed from the motivation of coordination with groups of female students, this department can be said to be quite good. In contrast to male students, since before learning to be brave, it is rather difficult to obtain academic and non-academic achievements. It just still needs more motivation from external parties (Family, Learning Environment and Lecturers).
\end{abstract}

Keywords: Online learning, student competitiveness, border areas

\begin{abstract}
Abstrak
Tahun 2018 merupakan tahun digencarkannya pembelajaran 4.0 dan society 5.0 yang mengandalkan jejaring sosial melalui jalur daring. Sejak pandemi covid terhitung awal tahun 2020 dan sejak diturukan peraturan dari Kemendikbud tentang perkuliahan tatap muka menjadi perkuliahan online mau tidak mau hampir semua kalangan masyarakat akhirnya memelajari hal tersebut. Banyak yang mengalami kesulitan menghadapi kondisi yang mendadak ini. Artikel ini akan membahas terkait daya saing/kompetitif mahasiswa PGSD mengikuti kuliah online yang berbasis pembelajaran 4.0 di Universitas Borneo Tarakan di masa pandemi covid 19 yang awalnya tatap muka menjadi perkuliahan online dari rumah. Artikel ini di lihat dari sudut pandang kualitatif, menggunakan pendekatan analisis naratif. Paparan data analisis akan dijelaskan dalam bentuk naratif. Hasilnya terdapat perbedaan signifikan antara daya saing mahasiswa dan mahasiswi mengikuti perkuliahan online, dari angkatan 2019 kelas A dan C. Banyak kendala yang mereka hadapi namun persentase potensi kompetitif mahasiswi PGSD lebih besar dibandinkan mahasiswa dalam mengikuti menghadapi kendala pada proses perkuliahan online. Jika dilihat dari motivasi koordinasi dengan kelompok mahasiswa perempuan jurusan ini dapat dikatakan cukup baik. Berbeda dengan mahsiswa laki-laki sejak sebelum pembelajaran daring memang agak sulit termotivasi untuk memperoleh prestasi akademik maupun non akademik. Hanya masih membutuhkan motivasi lebih dari pihak ekstern (Keluarga, Lingkungan Belajar dan Dosen).
\end{abstract}

Kata kunci: Pembelajaran online, daya saing mahasiswa, kawasan perbatasan 


\section{PENDAHULUAN}

Sejak akhir tahun 2019 hingga 2021 merupakan tahun yang sedikit sulit bagi dunia. Sektor ekonomi, pendidikan, kesahatan menurun tajam. Dewi (2020) mengungkapkan faktor pendidikan pun tidak urung terkena dampak dari covid 19. Segala mobilitas yang biasa dikerjakan di luar rumah harus mengalami hambatan dikarenakan penyebaran virus covid 19. Savitri (2019) mengangkat artikel tentang pendidikan di Kawasan perbatasan yang kompleks dengan kendala. Wilayah perbatasan yang identik dengan kawasan yang tertinggal dan terisolir membuat kehidupan masyarakat kurang baik. Di Kawasan ini pendidikan bukan menjadi prioritas utama bagi masyarakatnya.

Banyak masyarakat yang beranggapan bahwa pendidikan tidak bisa memberi mereka makan, karena mereka berpikir masih banyak lulusan sarjana yang hanya menjadi beban orangtua. Bahkan di Kota Tarakan saja masih terdapat orangtua yang buta aksara. Walaupun pemerintah sudah memfasilitasi gedung sekolah yang cukup memadai. Namun jika fasilitas yang ada berbanding terbalik dengan keinginan masyarakat memperoleh pendidikan maka juga akan menjadikan hasil pembelajaran yang kurang baik. Pembelajaran 4.0 dan Society 5.0 pun masih menjadi bagian yang sulit diaplikasikan di Indonesia terutama di kawasan perbatasan.

Pembelajaran 4.0 dan Society 5.0 menjadikan seluruh tenaga pendidik dan peserta didik mau tidak mau wajib menggunakan teknologi dalam proses pembelajaran. Semua tenaga pendidik maupun peserta didik wajib menggunakan aplikasi berbasis internet. sehingga setiap pendidik maupun peserta didik mau tidak mau harus mengenal serta memanfaatkan teknologi sebagai bahan belajar. Berkaitan dengan keterbatasan yang ada di kawasan perbatasan, terdapat beberapa peserta yang memiliki daya saing tinggi sehingga mampu mengikuti proses pembelajaran. Terdapat pula yang memiliki daya saing rendah dalam menyelasaikan masalah pembelajaran online.

Maka pada penelitian ini fokus kepada evaluasi daya saing mahasiswa Universitas Borneo Tarakan yang sebagian besar berasal dari kawasan perbatasan mengikuti pembelajaran selama pandemi, yang awalnya tatap muka menjadi kelas online. Dengan turunan poin, a) Keinginan Mahasiswa dalam bertanggungjawab melaksanakan tugasnya, b) Cara Mahasiswa Mengordinasi tugas bersama kelompok, dan c) Cara Mahasiswa megatasi kendala yang dihadapi. Ketiga turunan tersebut merupakan teori Need Achivement yang digagas oleh Mc. Clelland (Sudrajat, 2008) (Irawan, 2015) (Andjarwati, 2015) (Susanto \& Lestari, 2018)

\section{METODE}

Penelitian ini akan menggunakan metode kualitatif pendekatan analisis naratif tentang daya saing mahasiswa dan mahasiswi PGSD kelas A dan C dalam mengikuti pembelajaran online selama tahun ajaran genap 2019/2020 dan pandemi covid 19 di Universitas Borneo Tarakan yang banyak mahasiswanya berasal dari kawasan perbatasan. Berdasarkan analisis kondisi di atas, maka pendekatan penelitian yang dipandang sesuai dan relevan untuk menganalisis makna di balik pengamatan yang mendalam dengan menggunakan teknik wawancara dengan menggunakan instrument wawancara tertutup menggunakan aplikasi google form untuk kemudian menjadi pedoman wawancara mendalam dengan menggunakan telepon/ HP (Moleong, 2012).

Dari paparan data tersebut dapat dinyatakan bahwa penelitian kualitatif bersumber dari natural setting yang akan dijadikan sumber data langsung, sehingga makna hanya dapat dilakukan jika memeroleh atas kedalaman dari fakta yang 
diperoleh. Melalui pendekatan ini diharapkan dapat mendeskripsikan penemuan data secara menyeluruh mengenai penerapan penelitian. Sumber yang peneliti gunakan ialah dokumen hasil pelaksanaan wawancara selama pandemi pada tahun ajaran genap 2019/2020 sebagai bahan data yang nantinya dianalisis oleh peneliti.

\section{HASIL DAN PEMBAHASAN}

Sumber belajar yang dimanfaatkan biasa dirancang untuk kepentingan pencapaian tujuan pembelajaran. Banyak sekali sumber belajar yang dapat digunakan sebagai alat bantu pembelajaran. Sumber belajar ada yang digunakan di dalam ruangan dan di luar ruangan. Isi sumber belajar dsapat ditentukan seuai dengan inti pembelajaran yang akan diajarkan. Dosen merupakan profesi yang berkutat dalam dunia pendidikan. Seorang pendidik dapat disebut profesional jika memiliki kesiapan yang matang dalam malaksanakan proses pembelajaran. Bersedia megevaluasi setiap pembelajaran yang telah dilaksanakan sebagai bekal pembelajaran selanjutnya. Setiap saat mampu menciptakan inovasi dalam pembelajaran, bersedia mengajar dan mengembangkan bahan ajar mengikuti perkembangan teknologi dan jaman. Serta harus siap menghadapi dan mendesain kondisi mengajar yang berubah drastis secara tiba-tiba

Jika dikaitkan dengan revolusi 4.0 dan society 5.0 peran pendidik merupakan sosok yang bertugas membangun kemauan peserta didik dalam memeroleh softskill sehingga peserta didik yang mereka ajar dapat bersaing dengan perkembangan jaman. Aktifitas yang diajarkan pun juga berbeda-beda tergantung tujuan pembelajarannya. Pada era pembelajaran 4.0 dan society 5.0, internet merupakan sumber belajar yang dapat digunakan untuk membantu pencapaian pembelajaran.

Pada masa ini internet menjadi transformasi dalam kebudayaan. Savitri (2019) menyatakan bahwa penggunaan internet sudah menjamur di kalangan masyarakat. Namun dari data temuannya ini tidak berlaku di Kota Tarakan, Kalimantan Utara, karena pada saat hujan atau mati listrik jaringan internet di Kota Tarakan menjadi melambat. Sebagian besar kawasan di Kalimantan Utara merupakan kawasan perbatasan. Perbatasan atau yang sering disebut ruang dari suatu daerah dapat memiliki kesamaan atau bahkan perbedaan karaktersitik. Kawasan tersebut dapat ditinjau berdasarkan kondisi geografis dan sumber daya manusianya. Jika dilihat dari sudut pandang yang lain sebuah kawasan ini dapat memiliki potensi sumberdaya manusia yang berkualitas tinggi, sementara di kawasan lainnya memiliki kualitas sumber daya manusia yang rendah. Demikian halnya dalam hal sumber daya buatan manusia, bisa saja suatu kawasan telah memiliki infrastruktur yang sangat maju, sedangkan kawasan lainnya memiliki infrastruktur yang sangat terbatas. Kesamaan dan perbedaan kondisi kawasan tersebut dapat menjadi penciri yang menjelaskan karakteristik kawasan tersebut. Kawasan Sebatik merupakan kawasan yang dapat diamati perbedaannya, terlihat jelas antara daerah Indonesia dan Malaysia. Tingkat kesejahteraan dan infrastriuktunya pun berbeda. Savitri (2019) memaparkan bahwa transformasi internet di Kota Tarakan masih kurang berkembang ini akan menjadi lebih parah jika berada di Kawasan Perbatasan.

Bukan cuma sekali, kawasan di daerah perbatasan sering sekali mengalami pemadaman listrik. Pasalnya mahasiswa Universitas Borneo Tarakan bukan hanya berasal dari Tarakan, Banyak yang berasal dari kawasan perbatasan. Sejak awal turunnya anjuran dari kemendikbud tentang perkuliahan online dan pembatasan penularan covid 19, banyak orangtua yang meminta putra-putrinya kembali ke 
kampung halaman dengan dalih mengemat pengeluaran anggaran kos putra-putri mereka. .

Jika dikaitkan dalam proses pembelajaran ini merupakan tantangan bagi seorang pendidik era digital. Pembelajaran yang berkembang di era digital ini ialah pembelajaran 4.0 dan society 5.0 yang mununtut masyarakat bekutat di dunia digital.

Beberapa penelitian menjelaskan bahwa Pembelajaran society 5.0 merupakan sistem pembelajaran yang berpusat pada manusia dengan dukungan sistem yang mengintegrasikan dunia maya dengan dunia nyata untuk menghapus kesenjangan antar manusia, dan penyelesaian masalah sosial (Savitri, 2020; Indrawati, 2019; Gladden, 2019; Fukuyama, 2018). Gladden (2019) intinya society 5.0 terintegrasi dengan teknologi yang terus berkembang pesat yang dari pembelajaran 4.0 dan untuk mengintegrasikannya lebih mendalam ke dalam kehidupan sehari-hari. Ahmadi dan Ibda (2019) menyatakan bahwa revolusi industri yang terjadi begitu cepat membuat perubahan yang sangat signifikan karena tenaga manusia dan hewan digantikan oleh tenaga mesin. Salah satu aspek yang menarik untuk dikaji dari revolusi industri ini ialah sosok seorang pendidik dalam aspek kinerja. Karena kinerja pendidik menurut merupakan input yang paling penting dalam penyelenggaraan pendidikan (Nadeem \& et.al, 2011)

Penelitian ini fokus pada kemampuan mahasiswa dan mahasiswi PGSD kelas A dan $\mathrm{C}$ dalam berkompetisi melaksanakan pembelajaran yang bahkan di sana terdapat banyak kendala. Penelitian ini ingin melihat tingkat daya saing mahasiswa dan mahasiswi dalam melaksanakan pembelajaran daring setelah dosen mempersiapkan segala keperluannya dalam mengajar.

Setelah dilakukan penilaian kualitas perangkat pembelajaran, kemudian dilakukan penilaian sebelum dan setelah pemberian perangkat dalam proses pembelajaran terhadap motivasi dari proses pembelajaran. Hasil dari motivasi belajar disajikan pada Gambar 5.1, 5.2 dan 5.3.

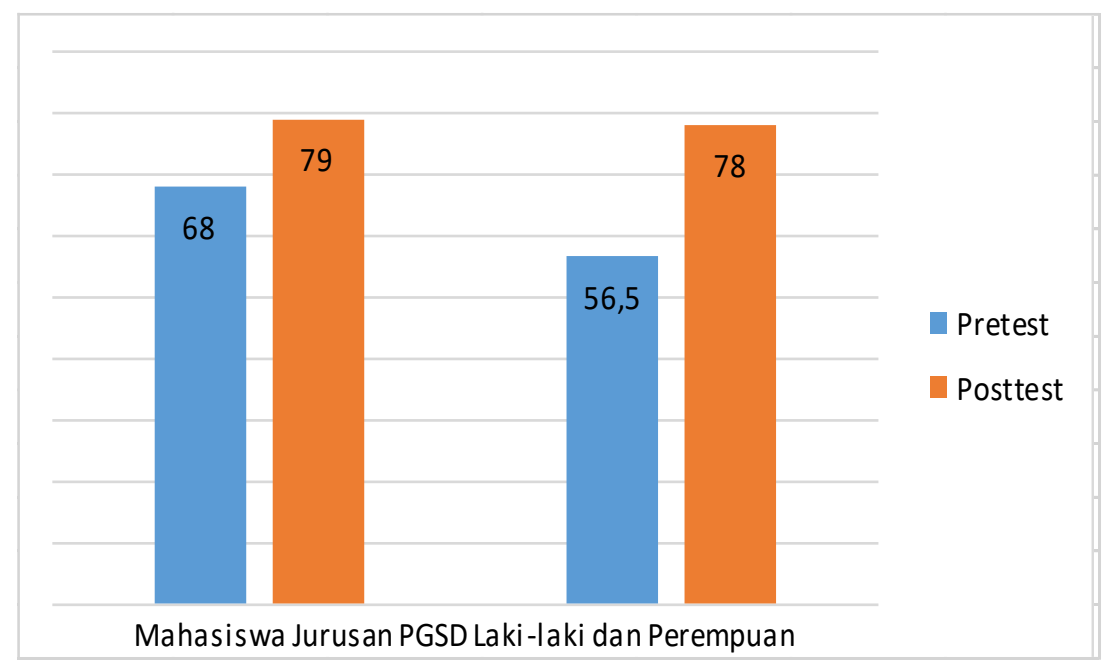

Gambar 5.1 Kemauan Mahasiswa mengikuti pembelajaran Daring 


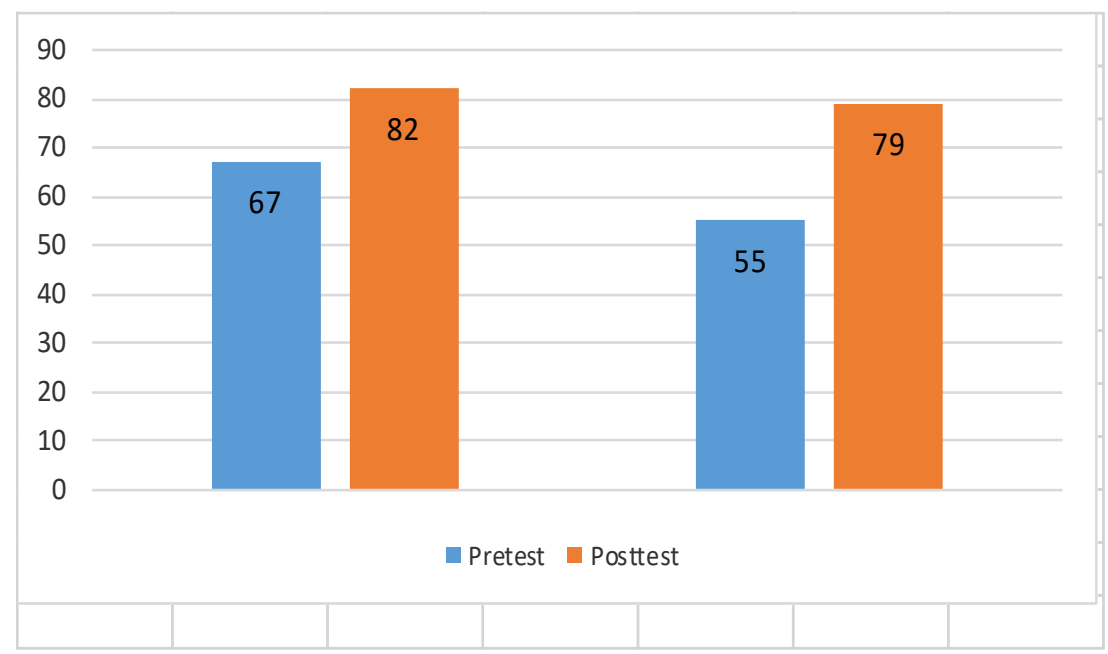

Gambar 5.2 Hasil Belajar Diskusi Kelompok

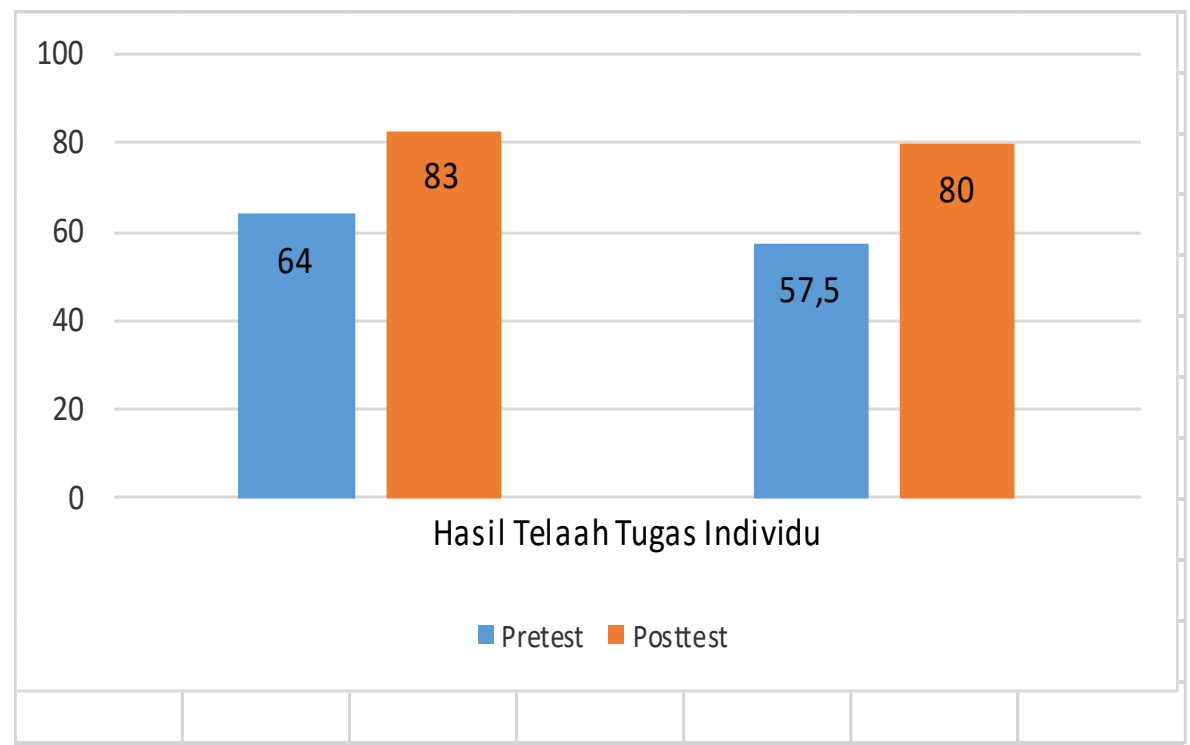

Gambar 5.3 Hasil telah Individu dalam Menyelesaikan Masalah

Dari paparan di atas yang berasal dari kuisiner kesiapan mahasiswa pada diagram 5.1 dapat dilihat bahwa keinginan mahasiswa laki laki untuk mengikuti pembelajaran sekitar $68 \%$ atau 13 mahasiswa dari kelas $A$ dan $56,6 \%$ atau 10 dari kelas C. Ini menunjukkan bahwa mahasiswa laki-laki di jurusan PGSD kelas A dan C masih membutuhkan banyak motivasi baik secara intern dan ekstern dalam bertanggungjawab menyelesaikan tantangan prestasi pada pembelajaran 4.0 dan society 5.0 .

Sedangkan $79 \%$ sebanyak 25 dari mahasiswa perempuan kelas A dan $78 \%$ atau sebanyak 26 Mahasiwa perempuan dari kelas C. Teori Mc. Clelland mengungkapkan motivasi berprestasi merupakan keinginan seseorang dalam mengarahkan dan mempertahankan tingkah laku untuk mencapai suatu prestasi. Kekuatan ini digunakan untuk menakhlukkan hambatan yang dianggap sulit. Paparan tersebut menampilkan jumlah presentase mahasiswa perempuan dapat dikatakan cukup baik walaupun masih dalam taraf cukup. Mahasiswi perempuan pun tidak luput dari kebutuhan 
perhatian akan motivasi dari ekstern agar lebih mampu bertanggungjawab menyelesaikan tugas. Baik mahasiswa laki-laki dan perempuan masih banyak yang memaparkan bahwa pembelajaran daring membutuhkan kuota dan jaringan yang stabil sangat memengaruhi proses pembelajaran yang mereka lakukan. .

Pada bagan 5.2 memaparkan hasil belajar dalam kelompok. Mahasiswa laki-laki dalam mengikuti diskusi kelompok juga lebih rendah dibandingkan mahasiswa perempuan sebanyak 67\% atau 13 mahasiswa laki laki dari kelas A dan 55\% atau 10 dari kelas $\mathrm{C}$. Keinginan mahasiswa perempuan mengalami peningkatan yang awalnya minim kesiapan menjadi lebih semangat dalam mengikuti prosesi diskusi di dalam kelas, yaitu $82 \%$ atau 25 mahasiswa dari kelas A dan $79 \%$ atau 26 mahasiswa peremupan dari kelas $\mathrm{C}$ menjadi lebih semangat dalam mengikuti proses diskusi di dalam kelas. Jika dilihat dari teori motivasi berprestasi Mc Clelland terkait daya saing yang digunakan untuk menakhlukkan hambatan yang dianggap sulit. Selalu berusaha menyelesaikan hambatan dengan menggunakan cara-cara yang kreatif. Selalu berusaha meningkatkan kemampuan dalam meraih prestasi. Presentase pada tahap ini dapat dikatakan dalam curva yang baik.

Diagram 5.3 memaparkan kinerja tugas individu 64\% atau 13 mahasiswa laki-laki dari kelas A dan 57,5\% atau 10 mahasiswa laki-laki dari kelas C. Begitu pula hasil belajar mahasiswa dalam mengerjakan tugas mandiri sebanyak $83 \%$ atau 25 mahasiswa perempuan dari kelas $A$ dan $80 \%$ atau 26 mahasiswa perempuan dari kelas C. Jadi dapat terlihat bahwa kemampuan menganalisis tugas mahasiwa PGSD angkatan 2020 lebih unggul pada mahasiswa perempuan dibandingkan mahasiswa laki-laki. Teori motivasi berprestasi dari Mc. Clelland yang memaparkan bahwa seseorang yang ingin mencapai sebuah prestasi selalu berusaha menyelesaikan hambatan dengan menggunakan cara-cara yang kreatif. Selalu berusaha meningkatkan kemampuan dalam meraih prestasi. Namun motivasi berprestasi mahasiswa PGSD di Tarakan sejak Covid 19 ini sangat membutuhkan upgrade dari pendidik maupun dari lingkungan sekitar mereka.

Beberapa hasil penelitian menjelaskan bahwa Pembelajaran society 5.0 merupakan sistem pembelajaran yang berpusat pada manusia dengan dukungan sistem yang mengintegrasikan dunia maya dengan dunia nyata untuk menghapus kesenjangan antar manusia (Savitri, 2020; Indrawati, 2019; Gladden, 2019; Fukuyama, 2018). Gladden (2019) intinya society 5.0 terintegrasi dengan teknologi yang terus berkembang pesat yang dari pembelajaran 4.0 dan untuk mengintegrasikannya lebih mendalam ke dalam kehidupan sehari-hari.

Savitri (2019) menyatakan bahwa penggunaan internet sudah menjamur di kalangan masyarakat. Namun dari data temuannya ini tidak berlaku di Kota Tarakan, Kalimantan Utara, karena pada saat hujan atau mati listrik jaringan internet di Kota Tarakan menjadi melambat. Sebagian besar kawasan di Kalimantan Utara merupakan kawasan perbatasan. Perbatasan atau yang sering disebut ruang dari suatu daerah dapat memiliki kesamaan atau bahkan perbedaan karaktersitik. Kawasan tersebut dapat ditinjau berdasarkan kondisi geografis dan sumber daya manusianya. Jika motivasi berprestasi dikaitkan dengan pembelajaran 4.0 dan society 5.0 di Kota Tarakan ini masih sangat kyrang mendapatkan dukungan dari segi motivasi berprestasi maupun jaringan yang stabil di Kawasan Perbatasan. 


\section{SIMPULAN}

Hasil Penelitian dari daya saing mahasiswa laki-laki dan perempuan jurusan PGSD Angkatan 19 Universita Borneo Tarakan-yang memang menaungi mahasiswa dari daerah perbatasan- pada perkuliahan menyatakan bahwa motivasi belajar mereka mengalami kendala keterlambatan jaringan, kekurangan dana membeli paket internet, ketiadaan alat sebagai support belajar. Faktor lain yang menyebabkan rendahnya daya saing mahasiswa laki-laki dan perempuan jurusan PGSD angkatan 19 di kelas A dan C perubahan drastis dari pembelajaran tatap muka menjadi pembelajaran daring yang harus menggunakan jaringan yang stabil.

Dari hasil pemaparan pun tampak perbedaan dari kemampuan mahasiswa lakilaki dan perempuan dalam menempuh proses pembelajaran. Jika prosentase jumlah semangat mahasiswa dari kelas $A$ dan $C$ dijadikan rata-rata maka $\{(68 \%+56,5 \%): 2=$ $62,25 \%$ k keinginan mahsiswa dari kelas $A$ dan $C$ untuk mengikuti pembelajaran sebanyak $62,25 \%$. Sedangkan kemampuan mahasiswi kelas A dan C dalam mengikuti pembelajaran daring hasilnya lebih signifikan yaitu $\{(79 \%+78 \%): 2=78,5 \%\}$. Begitupun hasil belajar diskusi Mahasiswa Kelas A dan $\mathrm{C}$ menunjukkan $\{(67 \%+55 \%=61 \%\}$. Hasil belajar diskusi mahasiswi kelas $A$ dan $C\{(82+79): 2=80,5 \%\}$. Begitupun jika dilihat dari hasil kesesuaian tugas individu yang diinstruksikan mahasiswa kelas $\mathrm{A}$ dan $\mathrm{C}$ $\{(64 \%+57,5 \%): 2=60,75 \%)$, hasil pengerjaan tugas sesuai instruksi pada mahasiswi $\{(83 \%+80 \%): 2=81,5 \%)$. Tampak sekali perbedaan keinginan dan semangat kompetisi dari mahasiswa dan mahasiswi angkatan 2019 kelas A dan C Jika dilihat dari motivasi koordinasi dengan kelompok mahasiswa perempuan jurusan ini dapat dikatakan cukup baik. Berbeda dengan mahsiswa laki-laki sejak sebelum pembelajaran daring memang agak sulit termotivasi untuk memperoleh prestasi akademik maupun non akademik. Hanya masih membutuhkan motivasi lebih dari pihak ekstern (Keluarga, Lingkungan Belajar dan Dosen).

\section{DAFTAR PUSTAKA}

Ahmadi, F. dan Ibda, H. 2019. Konsep dan aplikasi Literasi Baru di Era Revolusi Industri 4.0 dan Society 5.0. Semarang: CV. Pilar Nusantara

Anwar, M. H. M. (2018). Menjadi Guru Profesional. Jakarta: Prenada media Grup.

Dewi, W. A. F. (2020). Dampak Covid-19 terhadap implementasi pembelajaran daring di Sekolah Dasar. Edukatif: Jurnal Ilmu Pendidikan, 2(1), 55-61.

Elihami, E. (2019). Implementasi Layanan Bimbingan Kelompok Dalam meningkatkan Higher Of Think Mahasiswa Berbasis Kampus Merdeka. EduPsyCouns: Journal of Education, Psychology and Counseling, 1(1), 79- 86.

Fukuyama, M. (2018). Society 5.0: Aiming for a New Human-Centered Society. Japan Spotlight Special Article 2. https://www.jef.or.jp/journal/

Gladden, M. E. (2019). Who will be the members of society 5.0 Towards an anthropology of technologically posthumanized future societies. Socai Science, 8(5), 148.

Hanoatubun, S. (2020). Dampak Covid-19 terhadap Prekonomian Indonesia. EduPsyCouns: Journal of Education, Psychology and Counseling, 2(1), 146-153.

Moleong, L.J. (2012). Metode Penelitian Kualitatif. Bandung: PT. Rosdakarya

Maggioli. (2004). Pengembangan Profesi Guru. Bandung: Alfabeta.

Markos, S., \& Sridevi, M. S. (2010). Employee Engagement: The Key to Improving Performance. International Journal of Busniness and Management, 5(12).

Muda, I., Rafiki, A., \& Harahap, M. R. (2014). Factors Influencing Employees Performance: A Study on the Islamic Banks in Indonesia. International Journal of Business and Social Science, 5(2). 
Nadeem, \& et.al. (2011). Teacher's Competencies and Factors Affecting the Performance of Female Teachers in Bahawalpur (Southern Punjab) Pakistan. International Journal of Business and Social Science 2 (19), 218.

Ondi, S., \& Aris, S. (2010). Etika Profesi Keguruan. Bandung: Rafika Aditama.

Savitri, D. I. (2019). Penggunaan pembelajaran 4.0 berbantuan aplikasi google classroom dan google form dalam mata kuliah ilmu sosial budaya dasar. Jurnal Borneo Saintek, 2(1), 20-25.

Savitri, D. I. (2020, March). Peran Guru SD di Kawasan Perbatasan pada Era Pembelajaran 5.0 dan Merdeka Belajar. In Seminar Nasional Pendidikan Dasar (Vol. 2).

Sutrisno, A., dkk. (2020). Pengantar Sosial Ekonomi dan Budaya Kawasan Perbatasan. Malang; Inteligensiamedia PT. Cita Intrans Selaras.

Saleh, F., Dzulkifli, Z., Abdullah, W. A., \& Yaakob, N. M. (2011). The Effect of Motivation on Job Performance of State Government Employees in Malaysia. International Journal of Humanities and Science, 1(4).

Soewarni, E. (2004). Kebijakan Pedoman Pengembangan Profesi. Jakarta: Rajawali Press.

Sudrajat, A. 2008. Teori-teori motivasi Tentang Pendidikan. http://akhmadsudrajat.wordpress.com/2008/02/06/teori-teori-motivasi/

Susanto, N.H. \& 2018. Mengurai Problematika Pendidikan Nasional Berbasis teori Motivasi Abraham Maslow dan David Mc.Clelland. Jurnal Lembaran IImu Kependidikan47(1). Universitas Negeri Semarang

Undang-Undang Nomor 14 Tahun 2005 tentang Guru dan Dosen. 